\title{
REVISITING THE QUIET LIFE HYPOTHESIS IN BANKING USING NONPARAMETRIC TECHNIQUES
}

\author{
Rolf FÄRE ${ }^{1}$, Shawna GROSSKOPF ${ }^{2}$, Joaquín MAUDOS ${ }^{3}$, \\ Emili TORTOSA-AUSINA ${ }^{4}$
}

\author{
${ }^{1}$ Department of Economics and Department of Agricultural and Resource Economics, \\ Oregon State University, Corvallis, USA \\ ${ }^{2}$ Department of Economics, Oregon State University, Corvallis, USA \\ ${ }^{3}$ Departamento de Análisis Económico and Instituto Valenciano de Investigaciones \\ Económicas (Ivie), Universitat de València, Avda. de los Naranjos, s/n, 46022 València, Spain \\ ${ }^{4}$ Departament d'Economia and Instituto Valenciano de Investigaciones Económicas (Ivie), \\ Universitat Jaume I, Campus del Riu Sec, 12071 Castelló de la Plana, Spain \\ E-mails: ${ }^{1}$ rolf.fare@oregonstate.edu; ${ }^{2}$ shawna.grosskopf@oregonstate.edu; \\ 3joaquin.maudos@uv.es; ${ }^{4}$ tortosa@uji.es (correspondingauthor) \\ Received 05 January 2012; accepted 31 August 2012
}

\begin{abstract}
Early studies testing the quiet life hypothesis in banking found strong evidence that banks in more concentrated markets exhibit lower cost efficiency levels. More recent studies have reexamined the issue in different contexts with mixed results. These approaches are based on stipulating a linear relationship between market power and efficiency in banking, which might be problematic, as suggested by the literature on efficiency analysis. We explore how bank cost efficiency measures are related to market power using flexible techniques, which are more consistent with those employed to measure efficiency in the first stage of the analysis. Our study focuses on the Spanish banking industry, which has been experiencing substantial change in the last few years, combining institutions with different ownership structures and business models. Results show that the relationship varies according to the level of market power, the component of efficiency evaluated (cost, technical or allocative) and the type of banking firm (commercial bank or savings bank), suggesting that the quiet life might be a reality only for some financial institutions.
\end{abstract}

Keywords: banking, efficiency, market power, nonparametric regression, savings bank, Lerner index, Data Envelopment Analysis.

JEL Classification: C14, C61, G21, L50.

\section{Introduction}

Over the last twenty years, the changes and challenges faced by most banking industries worldwide have prompted a remarkable interest in analyzing several industrial organization topics in banking. Indeed, as suggested by Rhoades (1997), during the past fifteen years or so there had been many industrial organization (IO)-related research in banking. Some of the industrial organization topics more profoundly examined in the banking literature relate to the structure-conduct-performance (SCP) paradigm (Bain 1956), and 
the ensuing efficient-structure (ES) hypothesis (Demsetz 1973). As reviewed by Berger et al. (2004), the early 1990s empirical banking studies analyzing the effects of concentration and competition were particularly concerned about whether the traditional SCP paradigm held for the U.S. banking industry. Although this literature is large, and despite the difficulties of summarizing results, most studies found that banks in more concentrated local markets - as measured by the Herfindal-Hirschman Index (HII), or $n$-firm concentration ratio $(\mathrm{CR} n)$ - charged higher rates on loans, and payed lower rates on retail deposits (Berger, Hannan 1989; Hannan 1991).

Although most findings were consistent with the exercise of market power under the SCP hypothesis (Hannan, Berger 1991; Neumark, Sharpe 1992), it was not unusual to obtain weak relationships between concentration and profitability when firms' market shares were included in the regressions. Therefore, paralleling the making in the industrial organization literature, some studies aimed to analyze the validity of the ES hypothesis in banking - according to which high concentration endogenously reflects the market share gains of efficient firms. Typically, such studies controlled for measures of $X$-efficiency and scale efficiency, allowing concentration and market share to be functions of these efficiency measures (Berger 1995). As for the SCP paradigm, the empirical evidence for the ES hypothesis was also weak.

In the context of the literature that analyzes the relationship between performance, market concentration and efficiency, other papers have focused on the study of the effect of market power on managerial efficiency. In particular, the quiet life hypothesis (Hicks 1935) is considered a special case of the market power hypothesis. This hypothesis postulates that the higher market power, the lower the effort of managers to maximize operating efficiency, a negative correlation thus existing between market power and efficiency. In the empirical testing of this hypothesis, market concentration measures are traditionally used as proxy for market power (Berger, Hannan 1998). However, as stated in Maudos and Fernández de Guevara (2007), recent studies show the limitations of using market concentration measures as indicators of banking competition (Berger et al. 2004; Maudos, Fernández de Guevara 2004; Fernández de Guevara et al. 2005; Claessens, Laeven 2004, 2005). Therefore, they propose to use other indicators of competition such as the H-statistics (Panzar, Rosse 1987), or the Lerner index (Lerner 1934).

Our study analyzes the relationship between market power and efficiency considering an alternative to the traditional means used to evaluate the validity of either the SCP or ES hypotheses. Specifically, we employ nonparametric methods which are highly appropriate when a theory is lacking to evaluate the associations between two variables. Although theories are well established in our case, the mixed empirical evidence suggests they might be more difficult to test than one a priori might expect. Earlier initiatives, such as Clark (1986), considered similar issues, arguing that tests of the structureperformance paradigm yielded quantitatively small statistical significance because of the methodology employed. However, in contrast to a less restrictive nonparametric approach, his analysis was entirely confined to the parametric field, therefore disallowing more flexible interpretations of the relationship. Some recent contributions have also dealt with the quiet life hypothesis and related issues, among which we can highlight the 
papers by Koetter et al. (2012), Delis and Tsionas (2009), Casu and Girardone (2006, 2009), and Turk Ariss (2010). Although their objectives are not exactly coincidental with those of Clark (1986), they do neither consider flexible techniques to examine the links between efficiency and market power like we do.

Actually, the issue as to how a given set of covariates influences the efficiencies obtained in the first stage of the analysis (which is what the test of the quiet life does when examining how market power impacts on efficiency) has not been properly addressed in banking. As indicated by Simar and Wilson (2007, 2011), most of this literature, usually referred to as "second-stage regressions", has been considering nonparametric methods such as Data Envelopment Analysis (DEA) in the first stage of the analysis and either ordinary least squares (OLS) or to bit regression in the second stage, relying on conventional methods for inference. This is problematic for a number of reasons, such as the correlation of DEA efficiency scores. In the particular case of the analysis of the quiet life hypothesis in banking, where the relationship between efficiency scores and market power is examined, the empirical evidence taking the severity of these issues into account is entirely yet to come. Our proposal follows the suggestions by BalaguerColl et al. (2007) and Illueca et al. (2009), who combined the use of efficiency scores obtained in the first stage with flexible techniques (nonparametric regression and conditional density estimation, respectively).

Our analysis is focused on the Spanish banking system. It is one of the five largest banking systems in Europe. It offers a scenario where profound changes took place some years ago imposed by the Single Market Program of the European Community: important deregulations such as interest rate deregulation, total removal of legal coefficients, legal homogenization of both commercial and savings banks, free entry for European Union banks - as long as they meet European Union legislation - removal of the restrictions on the geographical expansion of savings banks, implementation of new telecommunications technologies, etc. In order to achieve a full economic and monetary integration with the creation of the euro currency union in 1999, the higher competitive pressures - and the reduction of market power - would impel financial institutions to make an extra effort to enhance efficiency. In fact, the advance in the degree of financial integration in Europe that has taken place after the introduction of the euro has been accompanied by increasing internationalization and openness of the Spanish banking sector, as well as an increasing importance of the cross-border activity. In this context of increased competition, Spanish banks experienced an improvement in their efficiency levels (Maudos, Fernández de Guevara 2008).

The analysis of the Spanish banking sector has an additional attractive feature. The fact that in Spain there are financial institutions with different ownership structures, corporate governance and business models enables us to analyze whether the relationship between market power and efficiency varies with the type of bank. Specifically, in Spain there are three types of deposit institutions, private commercial banks, savings banks andcreditco-operative banks, although we focus on the first two as the credit cooperatives have a marginal market share (only $4 \%$ in terms of total assets). 
The study proceeds as follows. The next section surveys the literature of the relationship between efficiency and competition. Section 2 presents the methodology used to measure market power and efficiency, emphasizing the relevance of focusing on cost efficiency and its technical and allocative components, introducing both the method and results on market power and efficiency separately. Section 3 describes the data and the specification of banking inputs and outputs. Section 4 presents the results. Finally, the last Section concludes.

\section{The relationship between efficiency and competition: the quiet life hypothesis}

As it is mentioned in Maudos and Fernández de Guevara (2007), the literature on the relationship between competition and efficiency is related to the hypothesis that explains the relationship between market structure, efficiency and performance. According to the traditional SCP paradigm referred to in the previous section, firms in markets with higher concentration are able to earn extra profits as the result of collusion between the firms in the industry. Thus, this hypothesis postulates a positive relationship between performance and concentration, assuming that the higher the market concentration, the higher the firms' market power.

An alternative hypothesis establishes that the positive correlation between profitability and market concentration is spurious and simply proxies for the relationship between superior efficiency, gains in market share and, consequently, higher concentration. According to this ES hypothesis (Demsetz 1973) also referred to in the introduction, the effect of concentration on profitability vanishes once a proxy variable for efficiency is introduced as explanatory variable.

In this context, the quiet life hypothesis focuses on the effect of market power on efficiency. This hypothesis postulates that the higher the market power, the lower the effort of managers to maximize efficiency, a negative correlation thus existing between market power and managerial efficiency.

There are several reasons that can justify a positive relationship between higher levels of market power and lower efficiency levels (Berger, Hannan 1998). First, if firms can charge prices in excess to competitive levels, managers do not have incentives to work as hard to keep costs under control, enjoying a "quiet life". Second, market power may allow managers to pursue objectives other than revenue/profit maximization. Third, in a non-competitive environment, managers devote resources to obtaining and maintaining market power which raises cost and reduces cost efficiency. Finally, market power allows inefficient managers' behaviour to persist without any intention to pursue goals other than maximizing firm value.

In contrast to the views supporting the quiet life, there are alternative explanations advocating for the rejection of this hypothesis in the specific case of the banking industry. Taking into account the specific characteristics of banks, this type of firms can reduce problems inherent to them (such as asymmetric information, problems of adverse se- 
lection and moral hazard, etc.) by establishing long-term relationships with clients. As indicated by the literature on relationship banking (Petersen, Rajan 1995), banks with market power have lower costs of monitoring and transactions with borrowers. Under such circumstances, a positive relationship between market power and cost efficiency would emerge. Banks with market power may have cost advantages in screening certain groups of borrowers. In addition, market power allows banks to enjoy greater profits, which may create incentives to behave prudently, this behaviour leading to the selection of less risky activities with lower monitoring costs. Finally, banks with market power are under less pressure to increase the quality of banking services, decreasing consequently the operating costs.

Although the relationship between profitability, market concentration and efficiency of the banking industry has been tested in an important number of papers, the available empirical evidence on the quiet life hypothesis is scarcer. However, in the last few years there is a renewed interest in analyzing the links between efficiency and market power. After reviewing this recent literature one may conclude that the empirical evidence is not conclusive - i.e., it is mixed.

The recent available evidence is relatively ample. Berger and Hannan's (1998) results are consistent with the quiet life hypothesis as a negative relationship between cost efficiency and market power (proxied by market concentration) is found for the U.S. banking industry. For a sample of developing countries, Turk Ariss's (2010) results also support the quiet life hypothesis, considering that banks with more market power (proxied by the Lerner index) are also the least cost efficient. However, according to her, one should be cautious about this result, if we consider that it is likely that the higher costs associated with market power are eventually channeled to bank clients which, in turn, may feed into higher prices and possibly boost bank profit efficiency. Similarly, Delis and Tsionas (2009), using a panel of EMU banks, report a negative relationship between cost efficiency and market power. Similar results were found by Coccorese and Pellecchia (2010), whose results support the quiet life in the context of Italian banking, although the impact of market power on efficiency was not particularly remarkable in magnitude.

On the contrary, the contributions by Maudos and Fernández de Guevara (2007), Koetter et al. (2012), Fu and Heffernan (2009), Casu and Girardone (2009) reject the quiet life hypothesis. The first of these papers analyzes the relationship between market power (measured by the Lerner index) and cost efficiency for the EU-15 banking sector. Koetter et al. (2012) derive efficiency-adjusted Lerner indices for the U.S. bank holding companies. They conclude that the evidence on the relationship between competition and both cost and profit efficiency clearly rejects the quiet life hypothesis. Casu and Girardone (2009) find positive causation between market power (proxied by the Lerner index) and efficiency for five EU banking sectors. Finally, for the Chinese banking system, Fu and Heffernan (2009) do not find evidence to support the quiet life hypothesis, although a drawback of this paper (as in Berger and Hannan's) is that they use market concentration as proxy variable for market power. 


\section{Methodology}

\subsection{The measurement of market power}

There are basically two methodologies to measure the degree of competition in the banking industry. The first one is the structural approach that stems from the traditional SCP paradigm referred to above and that uses market concentration indices as proxy variable for market power under the assumption that the higher the market concentration, the higher the market power. The second one is the so-called "New Empirical Industrial Organization" (NEIO) approach which relies on non-structural models that infer market power from the observation of banks' conduct. Under this approach, competition measures are developed from theory of the firm models under equilibrium conditions and typically use some form of price mark-up over a competitive benchmark. In the Lerner index ${ }^{1}$, it is the mark-up of price over marginal cost and the divergence of price from perceived marginal revenue for the Bresnahan's measure (Bresnahan 1989). The higher the mark-up, the greater the market power. An alternative approach, developed by Panzar and Rosse (1987) - the so-called H-statistic ${ }^{2}$ - focuses on the degree to which changes in the input prices leads to subsequent changes in revenues provided that the industry in a long-run equilibrium.

As mentioned before, some contributions have shown the limitations of proxying bank competition intensity with concentration measures, pointing to the need of using alternative indicators. For this reason, we use a competition indicator from the new empirical industrial organization approach: the Lerner index.

The Lerner index measures the capacity to set interest rates above marginal costs as a proportion of prices. This market power indicator is usually derived from the MontiKlein model (Freixas, Rochet 1997) and has been empirically approached in several papers cited above. As we interested in getting an aggregate measure of market power for the whole banking activity, we use the total assets of each bank as our proxy for banking output. With this approximation, the Lerner index is defined as the ratio "(price of total assets-marginal costs of total assets)/price". The price of total assets is computed from bank-level data as the ratio of bank revenue/total assets. Marginal costs are estimated from a translog cost function with a single output (total assets) and three inputs (deposits, labor and physical capital). As a panel data set is available, the estimation of the cost function includes individual fixed effects and time effects, which allows to control for the effect of macroeconomic variables such as GDP growth and inflation rate.

\footnotetext{
${ }^{1}$ The estimation of the Lerner index in banking has been applied in the studies by Angelini and Cetorelli (2003), Fernández de Guevara et al. (2005, 2007), Maudos and Fernández de Guevara (2004, 2007), Carbó-Valverde et al. (2003, 2009), among others.

2 There is also an extensive literature that has been considering the H-statistic (Panzar, Rosse 1987). See, for example, Bikker and Groeneveld (2000), De Bandt and Davis (2000), Claessens and Laeven (2004), among others.
} 


\subsection{The measurement of efficiency}

Efficiency may be measured via a variety of methods. They fall under the broad categories of parametric and nonparametric methods. Several monographs provide accurate descriptions of the available methods (Fried et al. 2008). However, some relatively recent monographs lean towards either parametric or nonparametric methods. Some findings showing that results may differ greatly between parametric or nonparametric techniques might have deterred publication of new monographs describing both approaches. On this respect, the recent paper by Badunenko et al. (2012) provides an explicit comparison of SFA and DEA estimators. In addition to this, the evolution of parametric and nonparametric techniques has not been entirely equal. Up to the early nineties, both groups of techniques went through relevant progress ${ }^{3}$, but some of the most recent proposals have leaned towards the nonparametric field. Cazals et al. (2002) present a nonparametric estimator (order- $m$ ) which is more robust to extreme values than DEA (Data Envelopment Analysis) or FDH (Free Disposable Hull), similarly to the order-aestimator introduced by Aragon et al. (2005).

However, prices do enter the analysis using any of these new methods, and some of them carry difficulties in handling multiple outputs and multiple inputs. Yet in banking the availability of prices, and the multiple-input/multiple-output nature of the banking firms suggests previous nonparametric methods (such as DEA) may still be more advisable - at least until further progress is made in the aforementioned new fields of research. In addition, both the order- $m$ and order- $\alpha$ estimators, although presenting some relevant advantages with respect to DEA or FDH, have also certain limitations partly derived from the need to specify the $m$ (in the case of order- $m$ ) and $\alpha$ (in the case of order- $\alpha$ ) parameters, which may be involved.

Therefore, the set of activity analysis techniques presented and revised in Färe and Grosskopf (2004) is our reference for measuring efficiency. Let $x=\left(x_{1}, \ldots, x_{N}\right) \mathrm{R}_{+}^{N}$ be the input quantities, with associated prices $\omega=\left(\omega_{1}, \ldots, \omega_{N}\right) \in \mathrm{R}_{+}^{N}$, and $y=\left(y_{1}, \ldots, y_{M}\right) \in \mathrm{R}_{+}^{M}$ be the output quantities. Accordingly, total costs will be defined as $\omega x=\sum_{n=1}^{N} \omega_{n} x_{n}$. It is important to note that we are assuming both input and output quantities are divisible and, more importantly, both the costs and revenues they generate, respectively, are divisible as well. This is a critical issue in banking, since information disaggregated enough is not always available.

Technology is defined as:

$$
T=\{(x, y): x \text { can roduce } y\}
$$

and input requirement and output sets are defined as:

$$
L(y)=\{x:(x, y) \in T\}, y \in \mathrm{R}_{+}^{M}
$$

\footnotetext{
${ }^{3}$ The paper by Berger and Humphrey (1997) surveyed 130 articles applying frontier efficiency analysis to financial institutions in 21 countries, which considered either parametric or nonparametric techniques in similar proportions. Fethi and Pasiouras (2009) provide a more updated survey of this literature, although confined entirely to the nonparametric case.
} 
and

respectively.

$$
P(x)=\{y:(x, y) \in T\}, x \in \mathrm{R}_{+}^{N}
$$

If $x_{s}^{*}$ and $y_{s}^{*}$ is the optimal input vector for firm $s, s=1, \ldots, S$, cost efficiency indexes will be defined as $C E_{s}=\omega_{s}^{\prime} x_{s}^{*} / \omega_{s}^{\prime} x_{s}$. The indexes will be bounded by unity from above, i.e., efficient firms will be those with efficiency scores equal to one - or 100, if results were expressed as percentages.

Optimal values are found by solving linear programming problem. For cost efficiency, the linear programming problem (where $\mathbf{X}$ and $\mathbf{Y}$ are observed data) for each $s$ firm is as follows:

$$
\begin{aligned}
\min _{\lambda, x_{s}^{*}} & \omega_{s}^{\prime} x_{s}^{*} \\
\text { s.t. } & -y_{s}+\mathbf{Y} \lambda \geq 0, \\
& x_{s}^{*}-\mathbf{X} \lambda \geq 0, \\
& 1 \lambda=1, \\
& \lambda \geq 0 .
\end{aligned}
$$

\subsection{Modelling the links between efficiency and market power}

OLS regressions assume the dependent variable of interest to be Gaussian distributed. But in our case, in which efficiency scores are bounded at unity, this assumption is clearly not met. The dependent variable must also be independently distributed. However, our efficiency scores are obtained using linear programming techniques and, therefore, this assumption is also violated, since firms' efficiencies are dependent in the statistical sense. This point has been forcefully made by Simar and Wilson (2007), who provide a valid alternative to these problems. See also the recent update by Simar and Wilson (2011).

The severity of this problem in the context of testing the quiet life hypothesis has been acknowledged by Koetter et al. (2012), who coincides in stressing how problematic it is to conditioning competition measures on banks' efficiency estimates obtained using frontier techniques - i.e., second-stage regressions using efficiency for the dependent variable lead to inconsistent and biased results.

The arguments in the previous paragraph would suffice per se to discard testing the quiet life considering OLS, or any of its variants - when efficiency scores have been obtained using linear programming techniques. In addition to this, the difficulties that the (scarce) previous empirical studies might have faced in testing the quiet life may relate to the fact that they use regression techniques which focus on the average effect for the average bank. However, as indicated by Reichstein et al. (2010), there are cases in which "the devil might dwell in the tails", i.e. the sign and significance of a given coefficient might be driven by the behaviour of few firms. Therefore, under some circumstances OLS is not the most appropriate method, and more flexible alternatives which consider the entire distributions of efficiencies, the dependency structures among efficiency scores (in the statistical sense), and the way the relate to market power, are better. 
In addition to the rationale provided above, although using linear models may generally represent a valid alternative, sometimes their choice entails a fair preliminary approach and can be very restrictive, leading to departures from reality. Indeed, in econometrics, the assumption of statistical adequacy, or correct model specification has often constituted an important concern, and functional forms misspecified may lead to invalid tests for the hypotheses under discussion (i.e., the so-called "parametric straitjacket"). There are circumstances in which transformations and/or quadratic terms can be used to handle nonlinearities, but it should be kept in mind that their use can require a good deal of expertise and time. Therefore, it remains an open question as to why more flexible methods - such as nonparametric regression - are still far from overused by economists, despite the recent (and not so recent) advances in this field by both the statistics and econometrics' literatures (DiNardo, Tobias 2001).

Nonparametric regression ${ }^{4}$ allows us to understand how some variable of interest, in our case the efficiency ( $Y$ or, in our particular setting, $E F F$ ) of any particular decision unit, is affected by variations in some other variable $X$ (in our case, market power). The utmost advantage of this type of technique - compared to parametric methods such as linear or polynomial regression - is its absence of a priori assumptions concerning the particular functional form on the link between $Y$ and $X$.

As suggested by Jennen-Steinmetz and Gasser (1988), out of the three best-known estimators of the nonparametric regression problem - smoothing splines, $k$-nearest neighbour estimator, and kernel estimators - the large body of theoretical results regarding asymptotic properties of these estimators has so far not solved the problem as to which method is always best and, if not, under which circumstances each method is preferable $^{5}$. Several comparative studies exist such as Jennen-Steinmetz and Gasser (1988), and in an application to Engel curves estimation, see Engel and Kneip (1996). A comparison among the three most popular and easy-to-implement methods, namely, the kernel, the $k$-nearest neighbour, and the (cubic) spline smoothers, is performed in Härdle (1990), both in theoretical and empirical terms. Silverman (1984) has demonstrated that spline smoothing corresponds approximately to smoothing by a kernel method with bandwidth depending on the local density of design points.

The underpinnings of nonparametric regression methods can be found elsewhere, yet we provide some insights to make the exposition as self-contained as possible. For a particular data set $\left\{\left(X_{s}, Y_{s}\right)\right\}_{s=1}^{S}$, we are interested in estimating the mean response curve $m$ :

$$
Y_{s}=m\left(X_{s}\right)+\varepsilon_{s}, s=1, \ldots, S \text {. }
$$

\footnotetext{
${ }^{4}$ Some recent and not-so-recent monographs cover this topic; see, for instance, Li and Racine (2007).

${ }^{5}$ In addition, although many different methods have been proposed to construct nonparametric estimates of a smooth regression function, the attention devoted to the different smoothing methods has not been great. Among them, the kernel, $k$-nearest neighbour $(k-N N)$, orthogonal series and spline estimators have received far more attention than some others such as recursive techniques, the regressogram, convolution smoothing, median smoothing, split linear fits or empirical regression which notwithstanding represent satisfactory choices in some specific cases.
} 
It is often difficult to ascertain the particular nature of $m(\bullet)$, i.e., to know whether the relationship is linear, quadratic, growing in $X$, etc. In such cases nonparametric regression advantages turn out to be especially relevant.

We use a particular variant of nonparametric regression, namely, smoothing splines, which provide a seamless link with semiparametric approaches to regression. Other studies such as Bao and Wan (2004) have used this alternative, considering that in some circumstances the underlying theories are not capable of conveying sufficient information to enable a correct and successful specification of parametric models. The penalized (or $p$-splines) variant to smoothing splines (Ruppert, Carroll 2000) introduces a penalty to control for possible spatial heterogeneity in the regression function. Similarly to Kernel regression, $m$ in Equation (5) is assumed to be a smooth function equal to the conditional mean of $y_{s}$ given $x_{s}$, which is estimated using a regression spline model:

$$
\widehat{m}(x ; \boldsymbol{\beta})=\beta_{0}+\beta_{1} x+\ldots+\beta_{p} x^{p}+\sum_{k=1}^{K} \beta_{p+k}\left(x-\kappa_{k}\right)_{+}^{p} .
$$

Splines are essentially piecewise polynomials whose different polynomial segments are tied together at a series of knots in a way that insures certain continuity properties (Bao, Wan 2004). In Equation (6) the knots are represented by $\kappa_{1}, \kappa_{2}, \ldots, \kappa_{K}$, whereas $p \geq 1$ is an integer, $\boldsymbol{\beta}=\left(\beta_{0}, \ldots, \beta_{p}, \beta_{p+1}, \ldots, \beta_{p+K}\right)^{\top}$, with $\beta_{p}$ the coefficient of the $p^{\text {th }}$ knot, is a vector of regression coefficients, and $u_{+}^{p}=u^{p} /(u \geq 0)$. Since the number of knots determines whether the fit may be too rough, or too smooth (too many knots yield quite a rough fit), it may be relevant to constrain their influence. Penalized spline regression provides means for doing so, hoping to result into a less variable fit.

Equation (6) represents a spline model of general degree (i.e., a $p^{\text {th }}$-degree spline) in which, using truncated power functions, the basis is:

$$
1, x, \ldots, x^{p},\left(x-\kappa_{1}\right)_{+}^{p}, \ldots,\left(x-\kappa_{k}\right)_{+}^{p},
$$

which is known as the truncated power basis of degree $p$. When $p$ is odd, a set of basis functions spanning the space of $p^{\text {th }}$-degree polynomials with knots at $\kappa_{1}, \ldots, \kappa_{K}$ is:

$$
1, x, \ldots, x^{p},\left|x-\kappa_{1}\right|^{p}, \ldots,\left|x-\kappa_{k}\right|^{p} .
$$

Smoothing splines have a natural representation in terms of this type of functions, sometimes called radial basis functions. Specifically, we consider the cubic smoothing spline:

where $\hat{\beta}_{0}, \hat{\beta}_{1}$ and $\hat{\beta}_{11}, \ldots, \hat{\beta}_{1 K}$ minimize:

$$
\widehat{m}(x ; \boldsymbol{\beta})=\beta_{0}+\beta_{1} x+\sum_{k=1}^{K} \beta_{1 k}\left|x-\kappa_{k}\right|^{3},
$$

$$
\left\|y-X_{0} \beta_{0}-X_{1} \beta_{1}\right\|^{2}+\lambda^{3} \beta_{1}^{\top} \mathbf{K} \beta_{1}
$$

for some $\lambda \geq 0$ subject to:

$$
\mathbf{X}_{0}^{\top} \beta_{1}=0,
$$

where $\boldsymbol{\beta}_{0} \equiv\left[\beta_{0}, \beta_{1}\right]^{\top}, \boldsymbol{\beta}_{1}=\left[\beta_{11}, \ldots, \beta_{1 K}\right]^{\top}, \mathbf{X}_{0}=\left[1, x_{i}\right]_{1 \leq i \leq n}$, and:

$$
\mathbf{X}_{1}=\left[\left|x_{i}-\kappa_{k}\right|^{3}\right], \mathbf{K}=\left[\left|\kappa_{k}-\kappa_{k^{\prime}}\right|^{3}\right] \text {. }
$$


This is accomplished by specifying a knot sequence $\kappa_{1}, \ldots, \kappa_{K}$ using the basis functions $1, x,\left|x-\kappa_{1}\right|^{3}, \ldots, x-\kappa_{K} \mid . \lambda$ is a smoothing parameter which controls the trade-off between smoothness, and goodness of fit to the data. The larger the value of $\gamma$, the more the data will be smoothed to produce the curve estimate. $\lambda^{3} \beta_{0}^{\top} \mathbf{K} \beta_{1}$ is called a roughness penalty because it penalizes fits that are too rough, thus yielding a smoother result. We have followed Ruppert et al. (2003) regarding the choice of smoothing parameter and knots' position.

\section{Data, inputs, and outputs}

The Spanish banking system is made up of private commercial banks, savings banks, and credit co-operatives. For regulatory reasons, they have traditionally specialized in different lines of business. After the deregulation process that took place at the beginning of 1990 s, they now face exactly the same operational regulation, which allows them to undertake the same activities. The only regulatory differences among them arise from their types of ownership, as commercial banks are privately owned, savings banks are foundations, and credit co-operatives are mutually owned. This difference is subtle, as savings banks are allowed to acquire commercial banks, but the opposite does not hold, as the former are a mix of privately-and publicly-owned companies. In contrast, due to this ownership type, savings banks have substantial difficulties in gaining equity. In fact, in the period analysed in this paper, $50 \%$ of their profits had to be dedicated to increasing reserves. However, the three types of firms are still influenced by their historical specializations, although over the last few years firms' product mixes have varied greatly ${ }^{6}$. See Crespí et al. (2004) for deeper insights on the peculiar ownership type of Spanish savings banks.

As mentioned before, we concentrate our analysis in commercial banks and savings banks, considering that cooperative banks only represent $4 \%$ of the Spanish banking sector in terms of total assets. The data used in the article are provided by the Spanish Confederation of Savings Banks (Confederación Española de Cajas de Ahorro, CECA) and the Spanish Association of Commercial Banks (Asociación Española de Banca, AEB). This is the only public information available for Spanish commercial and savings banks at the individual firm level. Although the Bank of Spain provides some additional disaggregated information for different balance sheet categories, it is available only for aggregated data - i.e., commercial banks and/or savings banks considered altogether.

\footnotetext{
${ }^{6}$ The outbreak of the international financial crisis in 2007 and the subsequent economic crisis has affected many Spanish financial institutions severely, specially savings banks. This has partly occurred because of the concentration of many Spanish savings banks in the real state development and construction sector, dependence on wholesale market funding, excess capacity, small average size of institutions, loss of profitability, etc. As a result, some regulatory initiatives such as the Royal Decree-Law 9/2009 of 26 June 2009 and the Royal Decree-Law 11/2012 of 9 July 2010 have laid the legal foundations in Spain for the restructuring of the savings bank sector. According to the Bank of Spain, this restructuring was unavoidable due to the structural limitations associated with the legal nature of savings banks, such as the legal restrictions on raising high quality capital. This process of rapid change provides an extra interest to the analysis carried out here.
} 
Data come from each firm's balance sheet and profit and loss account. The overwhelming majority of firms making up the industry are considered in the study. The banks for which either missing or unreliable information (zero employees, etc.) were excluded from the study. Our sample represents more than $90 \%$ of total industry assets.

The period analyzed is 1992-2003. In 2004 there was a regulatory change so that bank public data are now published following a very different decomposition of the balance sheet items. There have been no institutional initiatives so far to provide a homogeneous database covering the years before and after 2004. We chose the pre-2004 period because it allows to include more years in the study and to analyze the impact of deregulation on market power and efficiency.

Specifying inputs and, especially, outputs, is often a controversial issue in banking. On the input side, our choice stands with most previous literature. We consider three inputs, namely, labour $\left(x_{1}\right)$, capital $\left(x_{2}\right)$ and purchased funds $\left(x_{3}\right)$. See Table 1 for specific definitions and summary statistics for year 2003. We can calculate prices for each input category since information on the costs they generate is also available - i.e., labour expenses, amortizations and other noninterest expenses, and financial costs, respectively. There exist three basic approaches to define bank output, namely, the asset, user cost, and value-added approach (Berger, Humphrey 1992). Most studies fall under the first category, basically due to data limitations. Many others have considered an "enlarged" version of the asset approach, considering not only that asset categories yielding revenues are to be considered outputs, but also that transaction deposits are also an output, since they may be considered a proxy for the provision of payment and safekeeping services provided by each bank. However, there is no available disaggregation for deposits, which severely restrains our choice.

Table 1. Definition of the relevant variables, 2003

\begin{tabular}{|c|c|c|c|c|}
\hline Variable & Variable name & Definition & Mean & Std. dev. \\
\hline \multicolumn{5}{|l|}{ Outputs } \\
\hline$y 1$ & Loans $^{\mathrm{a}}$ & All forms of loans & $10,218,555.16$ & $21,432,079.11$ \\
\hline$y^{2}$ & Fixed-income securities & Fixed-income securities & $2,090,161.71$ & $6,650,321.65$ \\
\hline$y 3$ & Other securities & $\begin{array}{l}\text { Other securities and } \\
\text { participating interests }\end{array}$ & $802,539.46$ & $3,210,842.41$ \\
\hline$y 4$ & Nontraditional output & Noninterest income (net) & $87,626.85$ & $215,877.86$ \\
\hline \multicolumn{5}{|l|}{ Inputs } \\
\hline$x 1$ & Labor: & Number of employees & 2,505 & $4,827.83$ \\
\hline$x 2$ & Capital $\ddagger$ & Physical capital & $185,679.47$ & $364,581.79$ \\
\hline$x 3$ & Purchased funds & All deposit categories & $12,446,063.86$ & $28,729,959.75$ \\
\hline \multicolumn{5}{|l|}{ Inputprices } \\
\hline$\omega 1$ & Wages \& salaries & Labor expenses $/ x 1$ & 51.287 & 10.627 \\
\hline$\omega 2$ & Price of physical capital & $\begin{array}{l}\text { (Amortizations }+ \text { other } \\
\text { noninterest expenses) } / x 2\end{array}$ & 0.987 & 1.994 \\
\hline$\omega 3$ & Price of purchased funds & Financial costs $/ x 3$ & 0.019 & 0.009 \\
\hline
\end{tabular}

Note: ${ }^{\text {an }}$ thousands of EUR. 
Taking into account the rationale presented above, we consider banks to provide four outputs: loans $\left(y_{1}\right)$, fixed-income securities $\left(y_{2}\right)$, other securities $\left(y_{3}\right)$, and nontraditional output $\left(y_{4}\right)$. Specific descriptions for each of them, along with descriptive statistics, are provided in Table 1. Our choice is also conditional on the available information on the revenues attributable to each output category. Following Rogers (1998), we have also considered a further category, namely, nontraditional output, based on Rogers' findings which pointed out that disregarding the new activities in which most banks engage (basically activities that provide financial services and generate fee income) leads to biased efficiency estimates for both cost, revenue, and profit efficiency.

\section{Results}

\subsection{Results on market power}

Figure 1 displays violin plots on the evolution of market power for all banking firms, commercial banks, and savings banks ${ }^{7}$. They show that market power has been increasing over time, regardless of the type of firm under analysis. However, several specificities emerge. Considering the entire banking industry (Fig. 1a), the median (the yellow circle inside each box) indicates that market power has been increasing over the sample period. However, there is still a remarkable amount of extreme behaviour, as shown by the long tails, both upper and lower. Although more than $50 \%$ of banking firms have Lerner indices above 0.4 in the 2000-2003 period, this did not occur in the preceding years. However, there is a remarkable number of firms whose market power is quite low, as indicated by the longer and thinner lower tail of the distributions. In sum, although this is a hypothesis which needs to be tested properly, the distribution of the Lerner index is stretching over the sample period, indicating that the new competitive and regulatory environment has had a relatively strong impact on market power.

The reasons explaining this evolution are multiple, and lie beyond the scope of this paper. However, some of them could be related to the differing trends found for commercial banks and savings banks. As indicated in Figure 1b, there is a remarkable amount of variability for commercial banks, whose violin plots indicate that the distance between the tails of the distribution is increasing. And this is not only attributable to the behaviour of the observations at both extremes of the distribution, since the central $50 \%$ of the probability mass (the "box") has also become bigger.

In contrast, savings banks show a different pattern. In this case, distributions are much tighter, indicating that homogeneity prevails among this group of banking firms. This is a relatively surprising finding, since the deregulatory initiatives (Tortosa-Ausina et al.

\footnotetext{
${ }^{7}$ The violin plots combine the advantages of the box plots with density traces in one diagram, by making the width of the box proportional to estimated density. Specifically, the density traces are plotted symmetrically to the left and the right of the (vertical) box plot. Note also that there is no difference in these density traces compared to the standard densities obtained, for instance, via kernel smoothing, other than the direction in which they extend. By adding two density traces we obtain a symmetric plot, which facilitates realizing the magnitude of the density. The box inside represents the interquartile range $(I Q R)$, containing the $50 \%$ midrange values of the variable analyzed, and the horizontal line inside the box is the median. This mix of the density trace and the box plot enables quick and insightful comparison of several distributions (Hintze, Nelson 1998).
} 

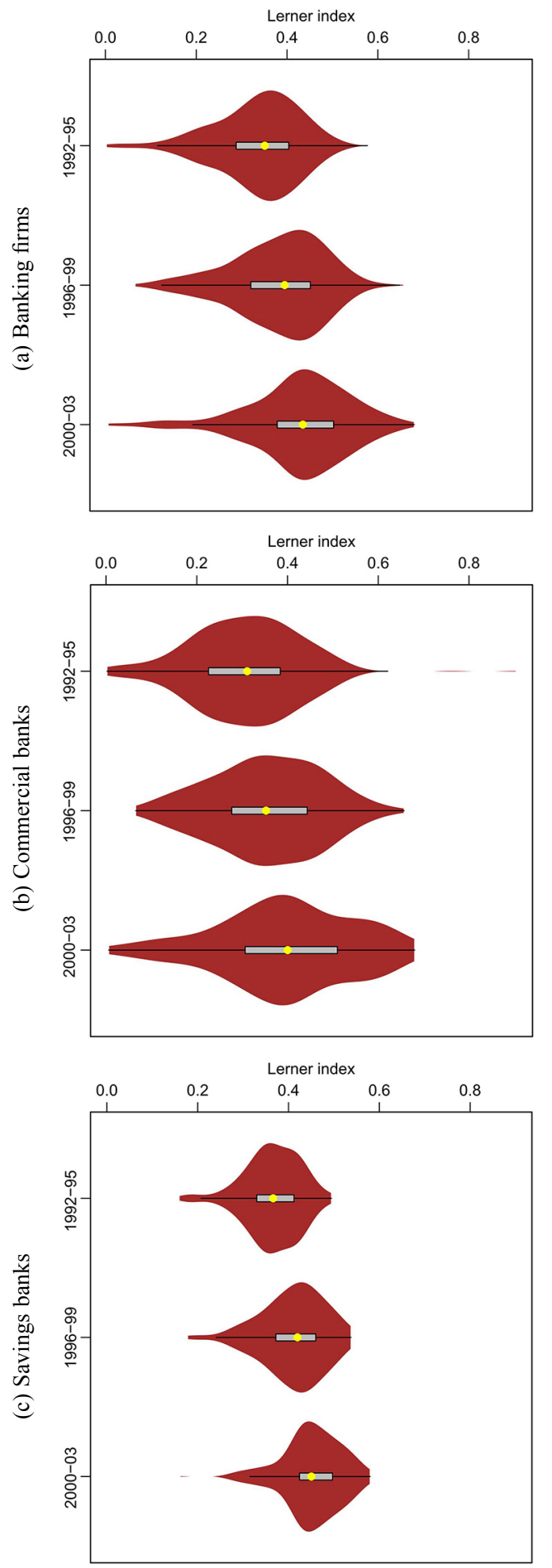

Fig. 1. Violins plots of market power (Lerner index), 1992-2003
2012) have enabled commercial banks and savings banks to face the same regulatory environment - they only differ in their type of ownership. However, discrepancies among savings banks in many fields (in this case, in terms of market power) are still minor.

We can consider a proper test in order to elucidate whether the differences among the different types of institutions are significant or not. Table 2 provides results on the $\mathrm{Li}$ (1996) test in order to ascertain whether results differ according to a variety of hypotheses, namely, we test whether market power distributions differ significantly when comparing both types of firms, and when comparing the different types of firms over time - i.e., 1992 vs. 2003, for which the relevant hypotheses are $H 0: f(\cdot)=g(\cdot)$, where $f$ and $g$ represent the relevant distributions. Details on the specifics of the test are provided not only in Li (1996), but also in other applications such as BalaguerColl et al. (2010). In brief, it consists of comparing two distributions based on kernel methods, making no assumptions on the shape of the distributions, and focusing on their entirety rather than simple summary statistics such as ANOVA, Kruskal-Wallis or Wilcoxon and related tests do. This is important because the average may mask important trends at firm level.

Results show that differences are always significant at the $1 \%$ significant level. When comparing commercial banks and savings banks, the null hypothesis of equality of distributions $\left(f\left(\right.\right.$ Lerner $\left.^{\text {Commercial banks }}\right)=g\left(\right.$ Lerne $^{\text {Sav- }}$ ings banks)) is strongly rejected. When comparing the distributions of the Lerner index at the initial and final sample years (1992 and 2003), although the test statistics are lower, the null hypothesis is also rejected at the usual 
Table 2. Distribution hypothesis tests ${ }^{\mathrm{a}}, 1992-2003$

\begin{tabular}{|c|c|c|}
\hline Null hypothesis $(H 0)^{\mathrm{b}}$ & $\begin{array}{c}T \text {-test } \\
\text { statistics }\end{array}$ & $\begin{array}{c}\text { 1-Percent significance } \\
\text { level (critical value }= \\
2.3263)\end{array}$ \\
\hline$f\left(\right.$ Lerner $\left.{ }^{\text {Commercial banks }}\right)=g\left(\right.$ Lerner $\left.^{\text {Savings banks }}\right)$ & 33.5789 & $H 0$ rejected \\
\hline$f\left(\right.$ Lerner $\left.{ }^{\text {Banking firms, 1992 }}\right)=g\left(\right.$ Lerner $\left.^{\text {Banking firms, 2003 }}\right)$ & 17.1974 & $H 0$ rejected \\
\hline$f\left(\right.$ Lerner $\left.^{\text {Commercial banks, } 1992}\right)=g\left(\right.$ Lerner $\left.{ }^{\text {Commercial banks, } 2003}\right)$ & 3.4918 & $H 0$ rejected \\
\hline$f\left(\right.$ Lerner $\left.{ }^{\text {Savings banks, } 1992}\right)=g\left(\right.$ Lerner $\left.^{\text {Savings banks, 2003 }}\right)$ & 15.9216 & $H 0$ rejected \\
\hline
\end{tabular}

Notes: a $f\left(\right.$ )and $g\left(\right.$ )are (kernel)distribution functions for market power; ${ }^{b}$ The null hypothesis tests for the equality of distributions $H 0: f(x)=g(x), \forall x$, against the alternative, $H 1: f(x)=g(x)$, for some $x$. Source: Li (1996).

significance levels, for all banking firms $(f$ (Lerner Banking firms, 1992 $)=g$ (LernerBanking firms, 2003)), commercial banks $(f$ (Lerner Commercial banks, 1992) = $g($ Lerner Commercial banks, 2003) $)$ and savings banks $\left(f\left(\right.\right.$ Lerner $\left.^{\text {Savings banks, } 1992}\right)=g($ Lern-

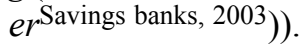

\subsection{Results on efficiency}

Tables 3, 4 and 5 display the results for cost, technical and allocative efficiency, respectively. Mean cost efficiency has been declining from 0.843 in 1992 to 0.698 by 1999 for all banking firms, reviving to reach 0.760 by 2003 . Commercial banks were the best performers; they departed from 0.912 , bottomed at 0.749 by 1999 , but ended up with efficiency levels similar to those of 1992. A similar pattern is found for savings banks, yet their efficiency is substantially lower. Savings banks also bottomed earlier, declining from 0.774 to 0.625 in 1998 , reaching 0.683 by the end of the sample period. Weighted values are higher in all instances, yet the inflection by the end of the nineties is mirrored. In this case, the inflection occurs earlier, suggesting that large firms could be leading in an industry characterized by rapid change.

Therefore, despite the intense regulatory initiatives, inefficiency not only persists but also increases over time. In addition, although all banking firms face the same regulation, and they can perform the same operations, cost efficiency differences, on average, are not fading away.

The decomposition of cost efficiency into their technical and allocative components is quite revealing, since the sources of inefficiency are identified. Technical efficiency (see Table 4) is remarkable, reaching mean values close to $100 \%$ in some cases. Firms' performances are much closer than in the cost and revenues cases, as revealed by much lower standard deviations. In contrast, allocative efficiency (Table 5) presents more instability, since it does not differ a great deal from technical efficiency at the beginning of the sample period, yet ends up being, on average, much lower. Therefore, when prices do not enter the analysis one faces an industry where most firms are close to the efficient frontier. However, when they are included, discrepancies are remarkable, driving efficiency downwards. 


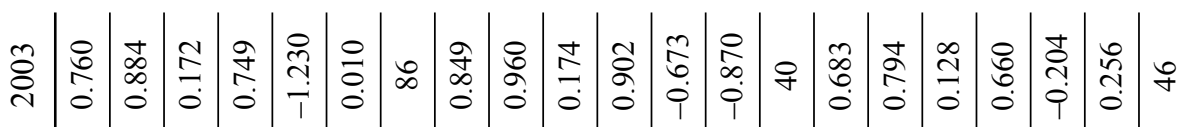

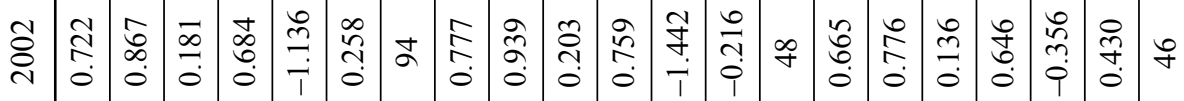

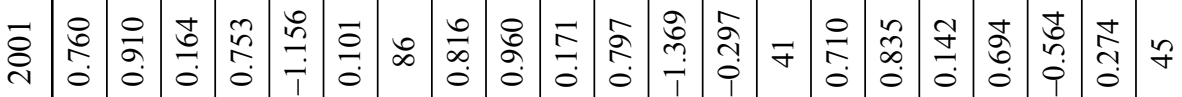

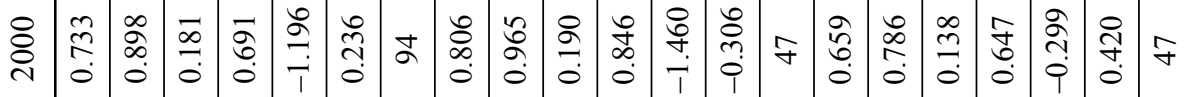

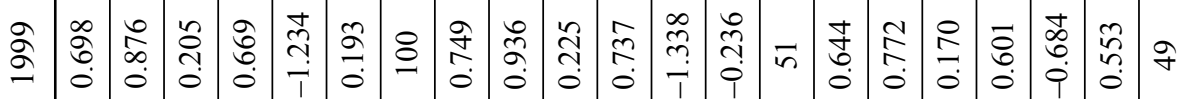

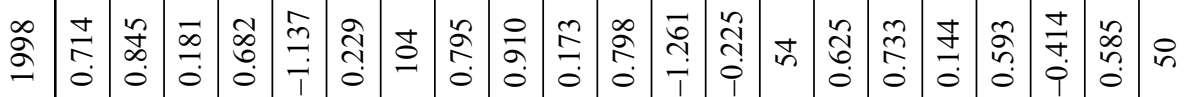

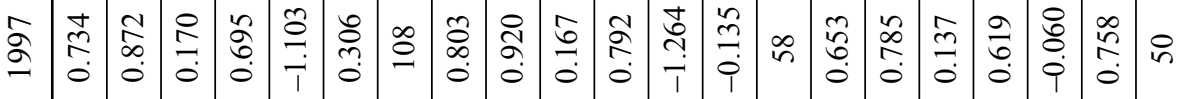

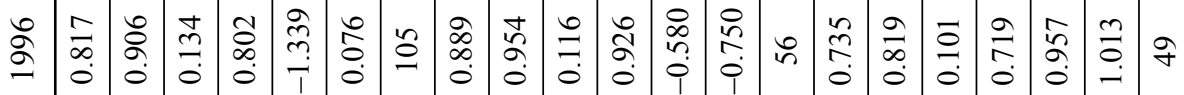

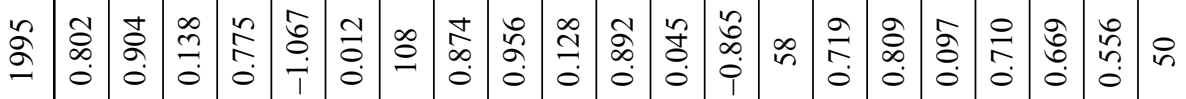

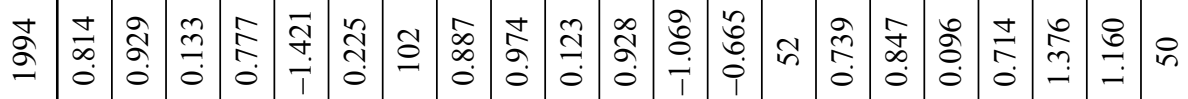

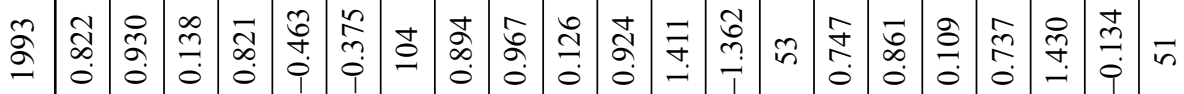

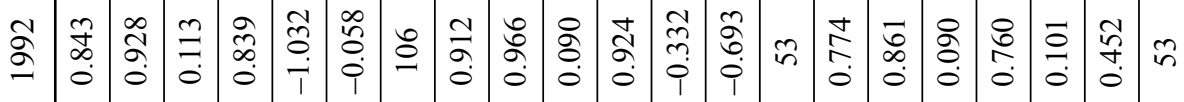

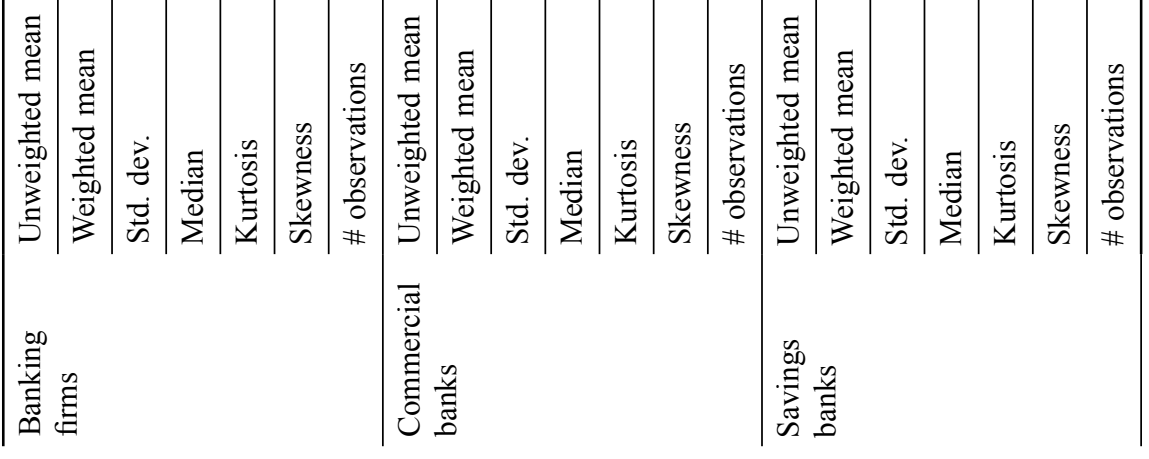




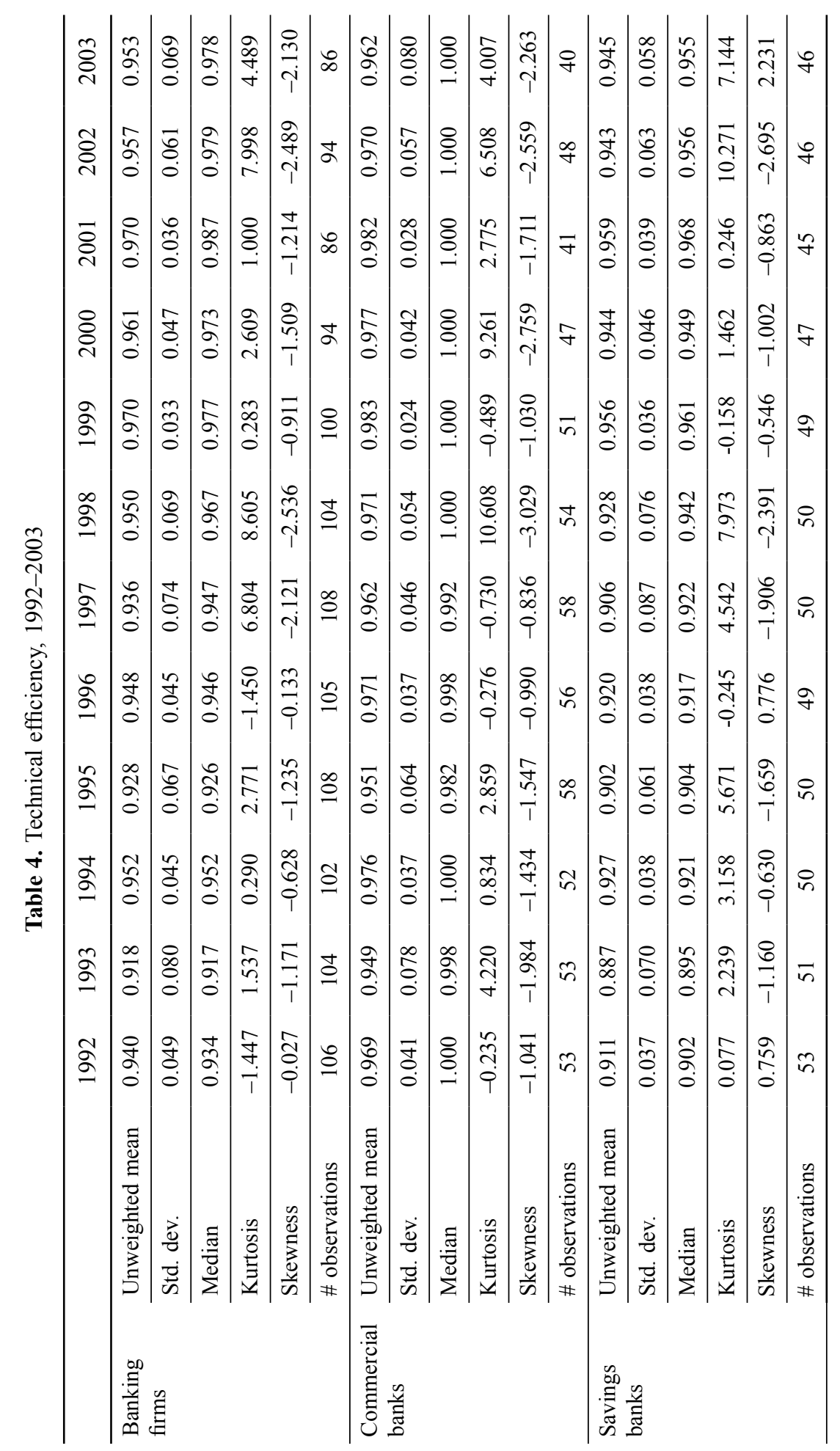




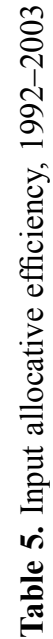

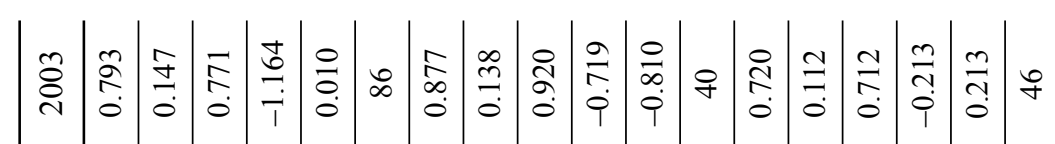

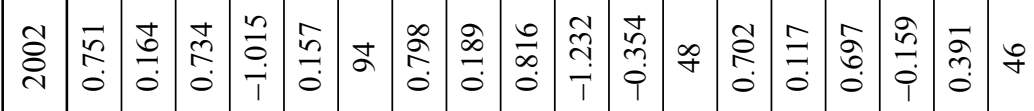

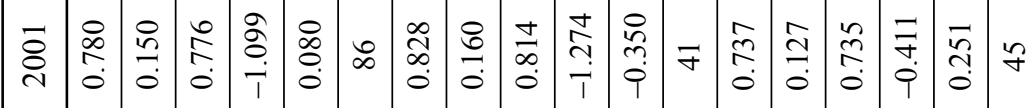

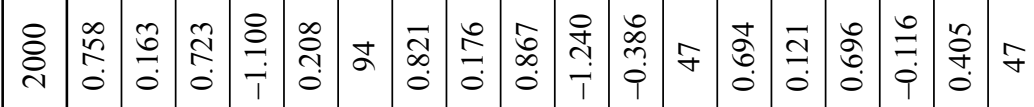

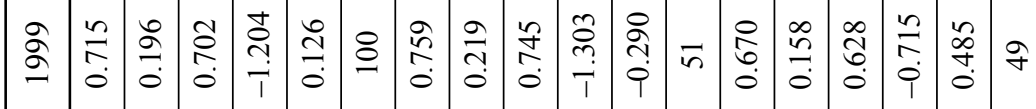

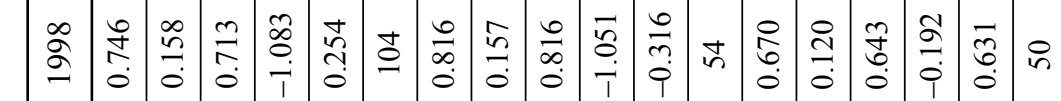

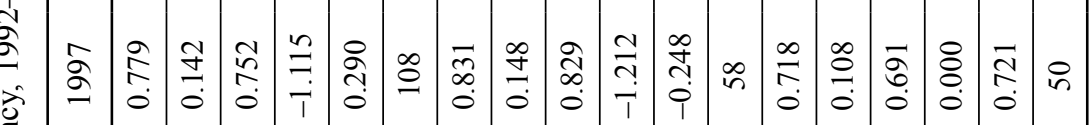

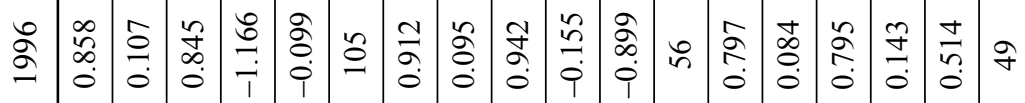

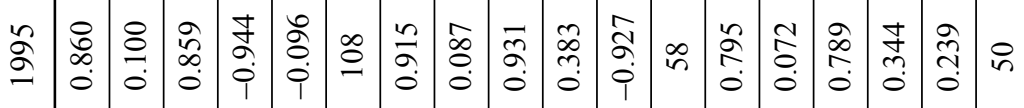

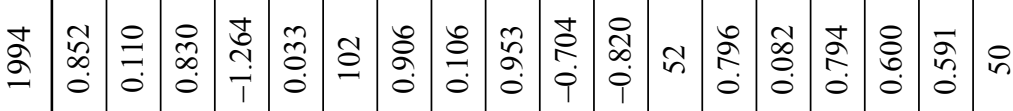

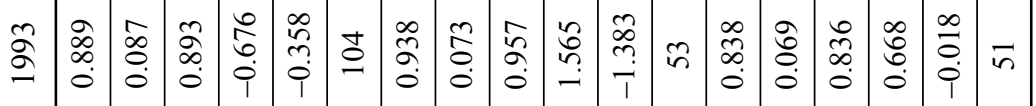

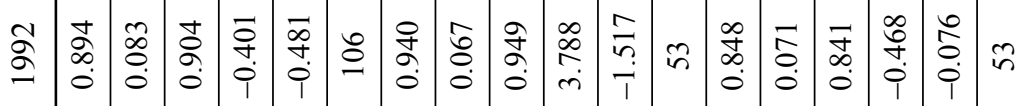

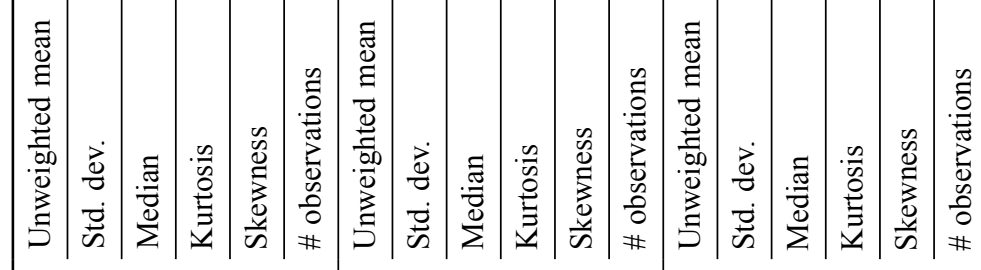

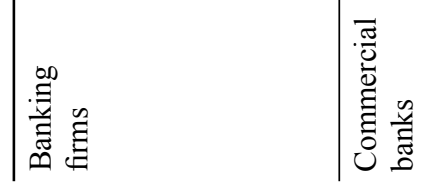

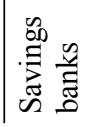


Although the variety of summary statistics are helpful for achieving better insights on the peculiar distributions of efficiencies, its informativeness is overshadowed by what more comprehensive, graphical based, indicators such as violin plots reveal. Violin plots on cost, technical and allocative efficiency are displayed in Figures 2, 3 and 4, respectively, for all types of banking firms. Considering the banking industry as a whole, Figure 2a indicates that discrepancies are important on the cost side, and they increase over time, as probability mass tends to become more spread. This points to a great variety of firm behaviour. These trends are not entirely coincidental when analyzing each type of banking firm, as shown in Figures $2 b$ and $2 c$. On the one hand, differences among commercial banks increase rapidly, and are very high; however, there are many efficient commercial banks. On the other hand, savings banks' behavior is much more homogeneous, although differences seem also to be growing.

The violin plots corresponding to technical and allocative efficiency (Figs 3 and 4, respectively) clearly corroborate the views provided by Tables 3, 4 and 5, indicating that the main contributor to cost inefficiency is its allocative component. This occurs regardless of the type of banking firm considered, but in the case of commercial banks technical efficiency is particularly high. However, although it has been increasing over the analyzed period, for both commercial and savings banks there are few firms which are much more inefficient than the rest, as shown by the long and thin tails.

\subsection{On the causality between efficiency and market power}

The links between market power and the variety of efficiency concepts considered here are explored in Figures 5-7 which show results on the links between efficiency and market power, for all cost, technical, and allocative efficiency and using penalized spline smoothing. We provide standard error bands - in particular, pointwise \pm 2 std. error bands - which provide a more precise view of the probability mass supporting the sign of the relationship. All estimations have been performed for the entire 1992-2003 period. Each figure contains three panels: banking firms, commercial banks, and savings banks. We have performed the analysis separately because, while it is true that both types of firms face the same regulatory environment and can perform exactly the same operations, strategies to respond to deregulation have differed a great deal.

When considering the relationship between market power and cost efficiency estimated via spline smoothing (Fig. 5), the difficulties of fitting a linear model are blatant due to the apparent nonlinearity of the relationship. When all banking firms are considered (Fig. 5a) the link shows a $U$-inverted functional form. For low levels of the Lerner index, the relationship is found to be positive, yet the wide standard error bands suggest significance is low. However, an inflection point is observed in the vicinity of Lerner $\approx 0.2$, when considering banking firms as a whole, and the regression line turns negative. Although the relationship between market power and cost efficiency becomes positive for high values of the Lerner index, the wide standard error bands, and also the number of observations (which are displayed on the $O X$ axis using short vertical bars) indicate that behaviour is caused by very few observations, therefore not providing statistical support to this claim. Therefore, Figure 5a gives support to these techniques as a relevant tool for testing the quiet life, since the negative relationship (supporting the "quiet life") does not hold for the entire conditional distribution. 

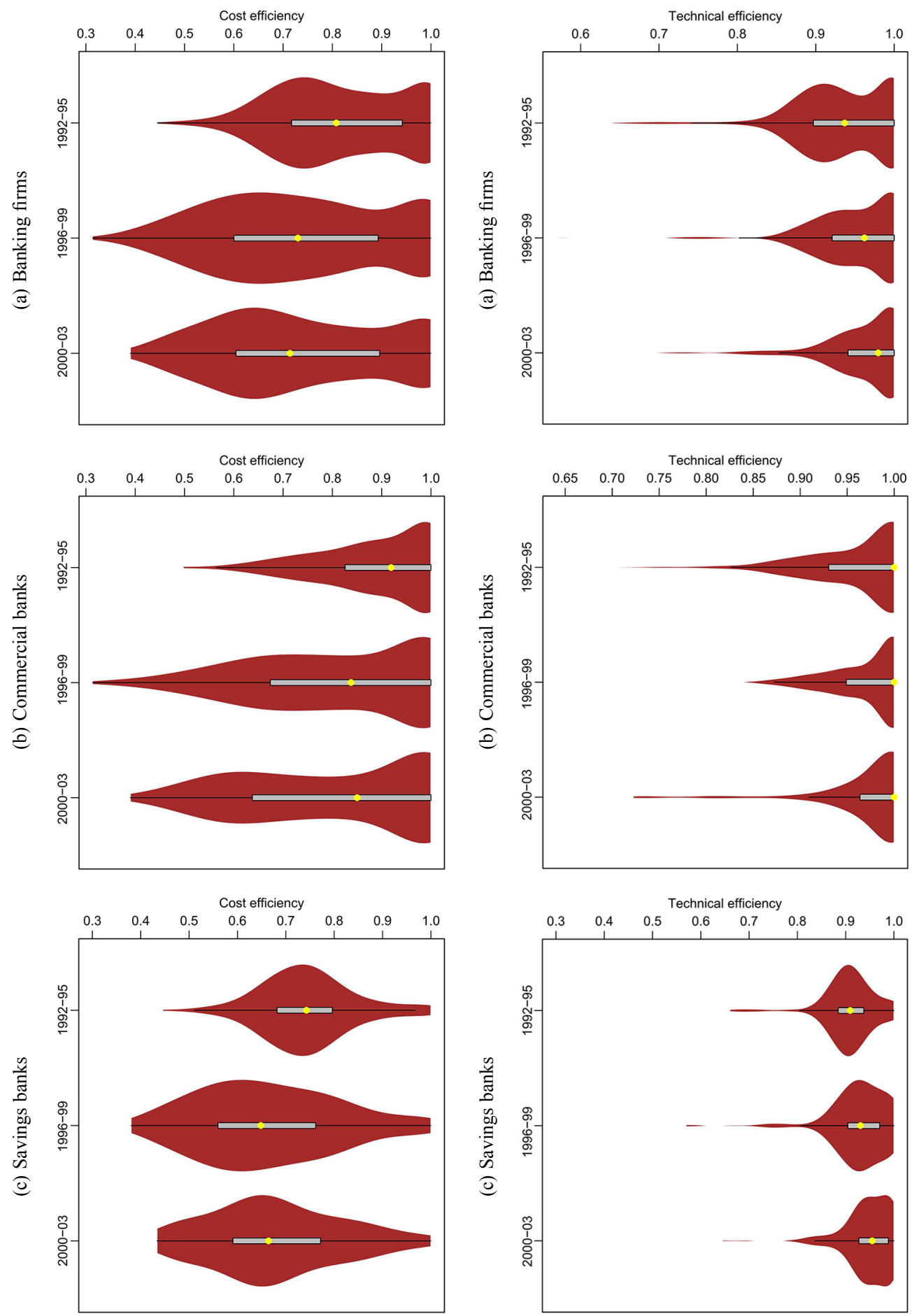

Fig. 2. Violin plots of banks' costefficiency, 1992-2003

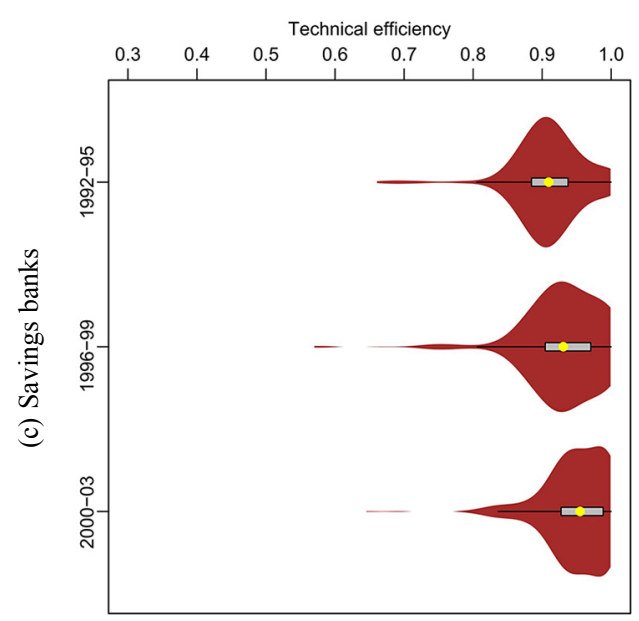

Fig. 3. Violin plots of banks'technicalefficiency, 1992-2003 
Results vary a great deal if performing the analysis separately for commercial banks and savings banks. As suggested by Figure $5 b$, cost efficiency has no apparent links with market power for commercial banks, as shown by the standard error bands. Therefore, the empirical evidence would be too weak either to support or reject the quiet life. Figure $5 \mathrm{c}$, on the other hand, suggests that the negative relationship found is mostly driven by savings banks.

As revealed by Figures 6 and 7, the patterns found for cost efficiency are mostly driven by their allocative components. The trend is apparent for either type of firm. In the case of technical efficiency, the sign of the relationship is mostly positive regardless of the type of firm under analysis, but especially for savings banks - which also showed the clearest tendencies for cost efficiency. In the case of banks, although the trend is unsteady, for the bulk of observations - ranging in the Lerner $\in(0.2,0.5)$ interval - the relationship is also positive. Therefore, allocative efficiency would be the main source for the types of relationships found for cost efficiency. As suggested in Figure 7, the shape is clearly $U$-inverted for commercial banks (especially for revenue efficiency) and mostly negative for savings banks.

\section{Concluding remarks}

Although several studies have analyzed the relationship between market power and efficiency in banking, the empirical evidence obtained to date is not conclusive. On the one hand, the studies by Berger and Hannan (1998), Delis and Tsionas (2009), Turk Ariss (2010), among others, support the quiet life
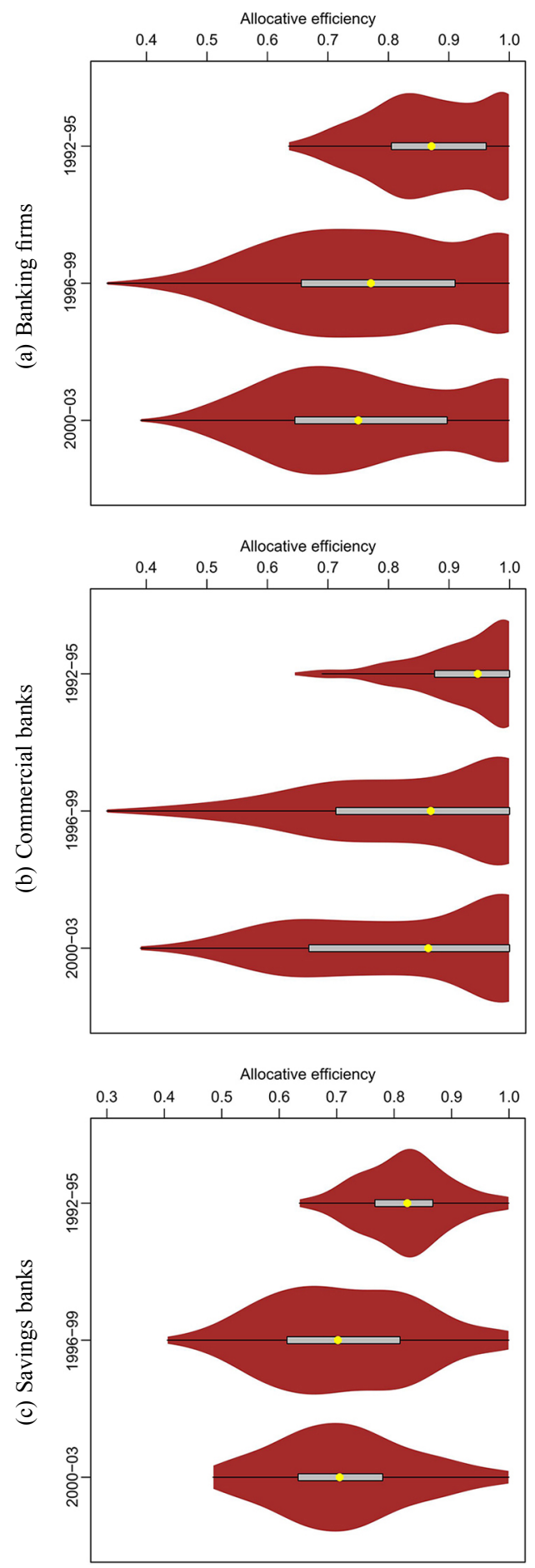

Fig. 4. Violin plots of banks' allocative efficiency, 1992-2003 

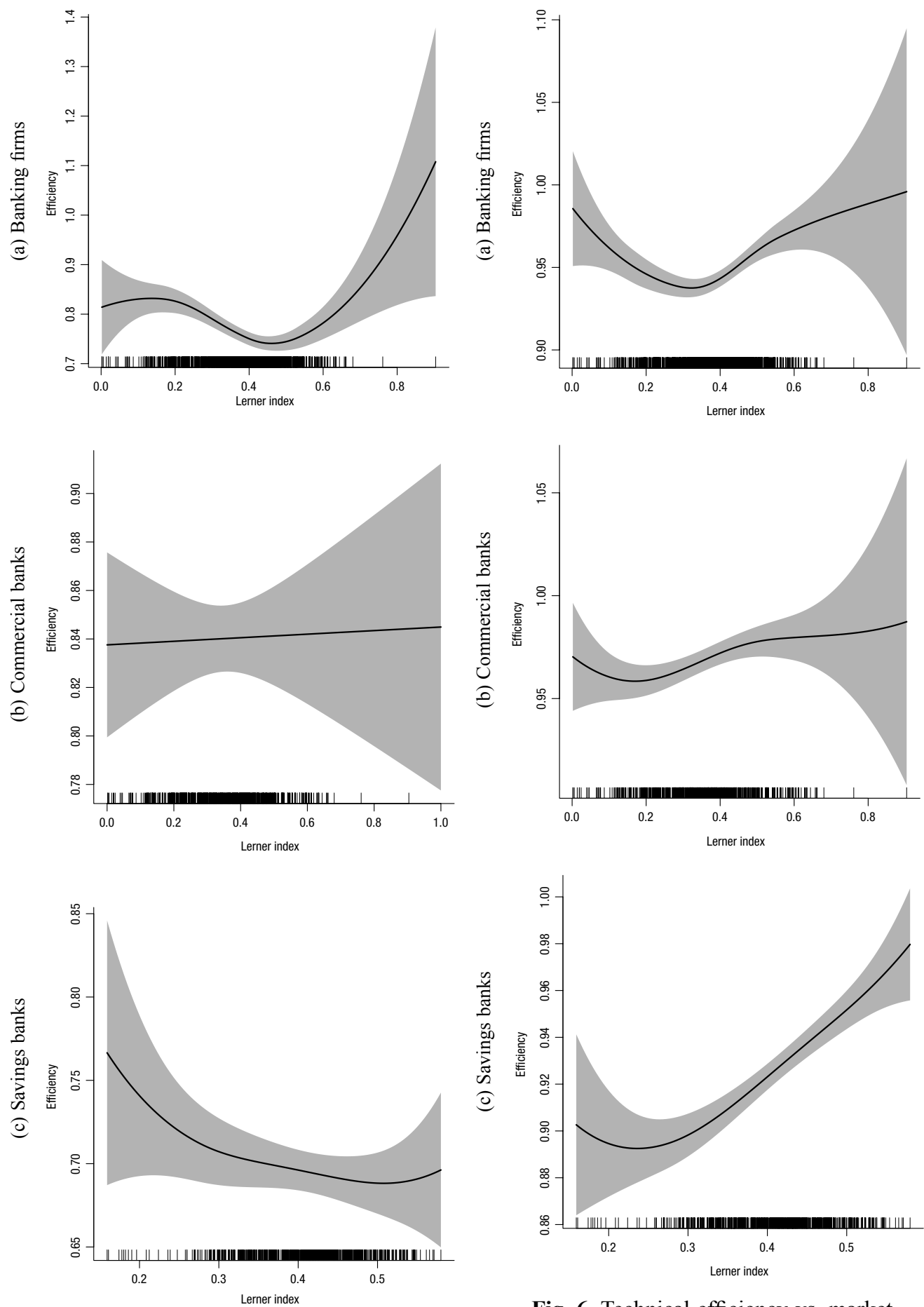

Fig. 5. Cost efficiency vs. market power (Lerner index), spline smoothing regression, 1992-2003

Fig. 6. Technical efficiency vs. market power (Lerner index), spline smoothing regression, 1992-2003 
hypothesis, according to which managers would translate higher inefficiencies into higher prices - as opposed to the efficient structure paradigm, where best practice allows firms to earn market power. On the other hand, papers by Maudos and Fernández de Guevara (2007), Casu and Girardone (2009), Fu and Heffernan (2009), Koetter et al. (2012), among others, reject that hypothesis. In this context, Casu and Girardone (2009) have recently pointed out that the relationship between competition and bank performance might be more complex, and the view that competition is unambiguously good might be particularly naïve in banking (Claessens, Laeven 2004).

Despite the view that the relationship between competition and efficiency is complex is becoming increasingly popular, there have been no attempts to explore the relationship assuming more flexible approaches, postulating no a priori relationship between market power and efficiency. This is precisely what we do in this paper. Specifically, we consider nonparametric regression techniques, which are appropriate in our particular setting not only because of their flexibility, but also because they do not confine the analysis to the average effect for the average bank, and for representing an alternative to OLS which "are invalid in this context due to complicated, unknown serial correlation among the estimated efficiencies" (Simar, Wilson 2007). Therefore, we consider a fully consistent approach in which nonparametric techniques are employed not only for measuring bank efficiency but also in the second stage of the analysis, in which a deeper understanding of the relationship between efficiency and market power is investigated.
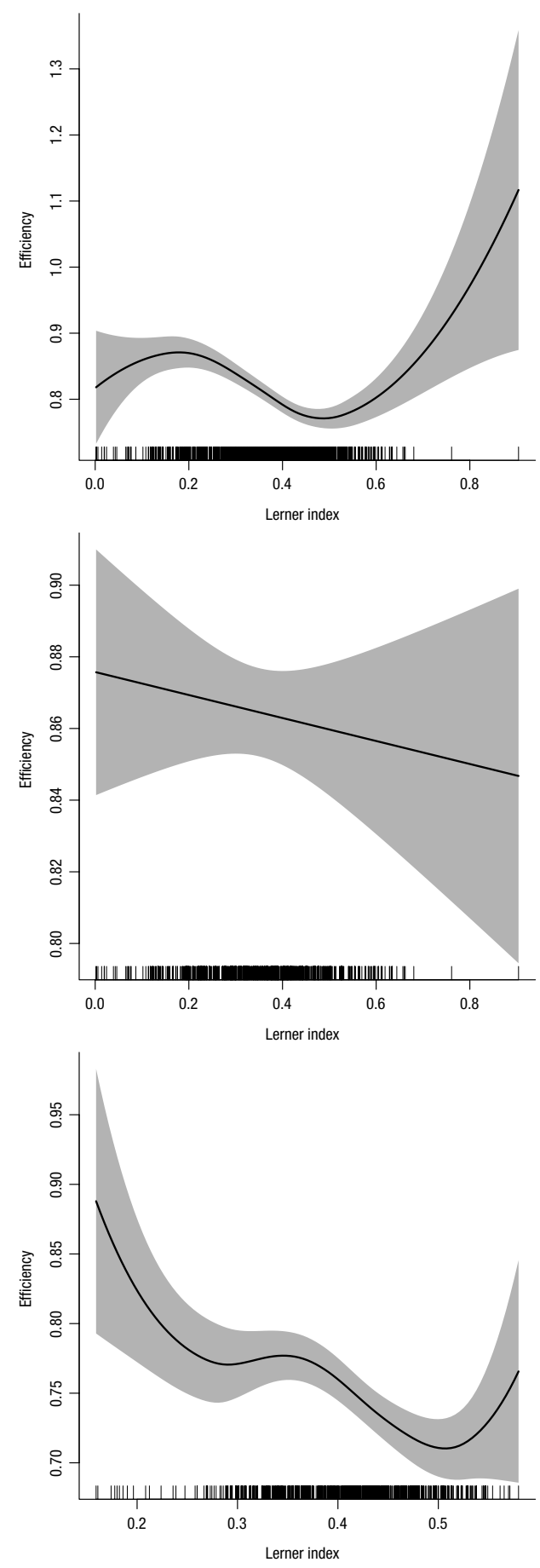

Fig. 7. Allocative efficiency vs. market power (Lerner index), spline smoothing regression, 1992-2003 
Our study is focused in the Spanish banking industry, one of the largest banking systems in Europe, which is changing dramatically in some aspects since the international financial crisis started. In particular, the specific savings banks' sub-sector is being reshaped rapidly, as the number of savings banks will be reduced almost to one third of that existing before the beginning of the crisis.

In this particular context, our results show that there are remarkable differences between commercial banks and savings banks' market power indicators, and also between the efficiencies found for both types of firms. In contrast to most previous studies, we conduct some tests which enable to conclude whether differences between the types of firms are significant or not. However, the most interesting finding is that, for the entire banking industry, the relationship between market power (measured using a non-structural indicator of the degree of market competition such as the Lerner index) and efficiency is not linear. The parameter that shapes the relationship between both variables is not constant along the distribution, indicating that the significance market power's impact on efficiency varies for each firm.

The analysis steps further by assessing how the different components of inefficiency technical and allocative - are linked to market power, using the same techniques. The analysis for technical efficiency, which sets prices aside, reveals also interesting trends: in this case, a positive relationship is found, especially for savings banks; on the other hand, when prices enter the analysis - allocative efficiency - we find that the relationship is either $U$-shaped or even negative which is, again, the case for savings banks. Therefore, we consider that examining the links between market power and efficiency would benefit not only by considering these flexible approaches but also from a decomposition of the type of efficiency being analyzed.

Therefore, comparing our results with those obtained in other studies that contrast the quiet life hypothesis shows the importance of analyzing separately the different components of cost efficiency, considering that the relationship between market power and technical efficiency presents peculiarities compared to the relationship with allocative efficiency. Similarly, given that our study, as far as we know, is the only one so far published that shows the non-linearity of the relationship between market power and efficiency in the specific case of the Spanish banking sector, it is necessary to obtain additional evidence in order to test whether this result is robust in other banking sectors. Actually, the different results achieved depending on the type of bank ownership structure and business model would point out to the need of obtaining additional evidence in other countries where competition among banks with different corporate governance structure exists.

\section{Acknowledgements}

We thank the comments by two anonymous referees as well as those by Daniel J. Henderson, Santiago Carbó, Mike Tsionas, Kristiaan Kerstens, Andrés Picazo, Aljar Meester, Russell Poskitt, and participants at the Australasian Finance and Banking Conference 2010 (Sydney, Australia). We also acknowledge the financial support of the Ministerio de Ciencia e Innovación (ECO2013-43959 and ECO2011-27227/ECON) and the Generalitat Valenciana (GVPROMETEOII2014-046). 


\section{References}

Angelini, P.; Cetorelli, N. 2003. The effects of regulatory reform on competition in the banking industry, Journal of Money, Credit, and Banking 35(5): 663-684.

http://dx.doi.org/10.1353/mcb.2003.0033

Aragon, Y.; Daouia, A.; Thomas-Agnan, C. 2005. Nonparametric frontier estimation: a conditional quantile-based approach, Econometric Theory 21(2): 358-389.

http://dx.doi.org/10.1017/S0266466605050206

Badunenko, O.; Henderson, D. J.; Kumbhakar, S. C. 2012. When, where and how to perform efficiency estimation, Journal of the Royal Statistical Society, Series A 175(4):

863-892. http://dx.doi.org/10.1111/j.1467-985X.2011.01023.x

Bain, J. S. 1956. Barriers to new competition. Cambridge, Massachusetts: Harvard University Press. http://dx.doi.org/10.4159/harvard.9780674188037

Balaguer-Coll, M. T.; Prior, D.; Tortosa-Ausina, E. 2007. On the determinants of local government performance: a two-stage nonparametric approach, European Economic Review 51(2): 425-451. http://dx.doi.org/10.1016/j.euroecorev.2006.01.007

Balaguer-Coll, M. T.; Prior, D.; Tortosa-Ausina, E. 2010. Devolution dynamics of Spanish local government, Environment and Planning A 42(6): 1476-1495. http://dx.doi.org/10.1068/a42506

Bao, H. X. H.; Wan, A. T. K. 2004. On the use of spline smoothing in estimating hedonic housing price models: empirical evidence using Hong Kong data, Real Estate Economics 32(3): 487-507. http://dx.doi.org/10.1111/j.1080-8620.2004.00100.x

Berger, A. N. 1995. The profit-structure relationship in banking - tests of market-power and efficient-structure hypotheses, Journal of Money, Credit, and Banking 27(2): 404-431.

http://dx.doi.org/10.2307/2077876

Berger, A. N.; Demirgüç-Kunt, A.; Levine, R.; Haubrich, J. G. 2004. Bank concentration and competition: an evolution in the making, Journal of Money, Credit, and Banking 36(3): 433-451. http://dx.doi.org/10.1353/mcb.2004.0040

Berger, A. N.; Hannan, T. H. 1989. The price-concentration relationship in banking, Review of Economics and Statistics 71: 291-229. http://dx.doi.org/10.2307/1926975

Berger, A. N.; Hannan, T. H. 1998. The efficiency cost of market power in the banking industry: a test of the "quiet life" and related hypotheses, Review of Economics and Statistics 80(3): 454-465. http://dx.doi.org/10.1162/003465398557555

Berger, A. N.; Humphrey, D. B. 1992. Measurement and efficiency issues in commercial banking, in Z. Griliches (Ed.). Output measurement in the service sectors: NBER Studies in Income and Wealth. Chicago: The University of Chicago Press, 245-300.

Berger, A. N.; Humphrey, D. B. 1997. Efficiency of financial institutions: international survey and directions for future research, European Journal of Operational Research 98: 175-212.

http://dx.doi.org/10.1016/S0377-2217(96)00342-6

Bikker, J. A.; Groeneveld, J. M. 2000. Competition and concentration in the European banking industry, Credit and Capital 33: 62-98.

Bresnahan, T. F. 1989. Empirical studies of industries with market power, in R. Schmalensee, R. D. Willig (Eds.). Handbook of industrial organization, vol. 2 of Handbook in economics, chapter 17. Amsterdam: Elsevier, 1011-1057.

Carbó-Valverde, S.; Humphrey, D. B.; Rodríguez-Fernández, F. 2003. Deregulation, bank competition and regional growth, Regional Studies 37: 227-237.

http://dx.doi.org/10.1080/0034340032000065398

Carbó-Valverde, S.; Udell, G. F.; Rodríguez-Fernández, F. 2009. Bank market power and SME financing constraints, Review of Finance 13(2): 309-340. http://dx.doi.org/10.1093/rof/rfp003 
Casu, B.; Girardone, C. 2006. Bank competition, concentration and efficiency in the Single European Market, The Manchester School 74(4): 441-468.

http://dx.doi.org/10.1111/j.1467-9957.2006.00503.x

Casu, B.; Girardone, C. 2009. Testing the relationship between competition and efficiency in banking: a panel data analysis. Economics Letters 105(1): 134-137.

http://dx.doi.org/10.1016/j.econlet.2009.06.018

Cazals, C.; Florens, J.-P.; Simar, L. 2002. Nonparametric frontier estimation: a robust approach, Journal of Econometrics 106: 1-25. http://dx.doi.org/10.1016/S0304-4076(01)00080-X

Claessens, S.; Laeven, L. 2004. What drives bank competition? Some international evidence, Journal of Money, Credit \& Banking 36(3): 563-583. http://dx.doi.org/10.1353/mcb.2004.0044

Claessens, S.; Laeven, L. 2005. Financial dependence, banking sector competition, and economic growth, Journal of the European Economic Association 3(1): 179-207.

http://dx.doi.org/10.1162/1542476053295322

Clark, J. A. 1986. Single-equation, multiple-regression methodology: is it an appropriate methodology for the estimation of the structure-performance relationship in banking?, Journal of Monetary Economics 18(3): 295-312. http://dx.doi.org/10.1016/0304-3932(86)90042-5

Coccorese, P.; Pellecchia, A. 2010. Testing the "quiet life" hypothesis in the Italian banking industry, Economic Notes 39(3): 173-202. http://dx.doi.org/10.1111/j.1468-0300.2011.00227.x

Crespí, R.; García-Cestona, M. A.; Salas, V. 2004. Governance mechanisms in Spanish banks. Does ownership matter?, Journal of Banking \& Finance 28(10): 2311-2330.

http://dx.doi.org/10.1016/j.jbankfin.2003.09.005

De Bandt, O.; Davis, E. P. 2000. Competition, contestability and market structure in European banking sectors on the eve of EMU, Journal of Banking \& Finance 24(6): 1045-1066.

http://dx.doi.org/10.1016/S0378-4266(99)00117-X

Delis, M. D.; Tsionas, E. G. 2009. The joint estimation of bank-levelmarket power and efficiency, Journal of Banking \& Finance 33(10): 1842-1850.

http://dx.doi.org/10.1016/j.jbankfin.2009.04.006

Demsetz, H. 1973. Industry structure, market rivalry, and public policy, Journal of Law and Economics 16(1): 1-9. http://dx.doi.org/10.1086/466752

DiNardo, J.; Tobias, J. L. 2001. Nonparametric density and regression estimation, Journal of Economic Perspectives 15(4): 11-28. http://dx.doi.org/10.1257/jep.15.4.11

Engel, J.; Kneip, A. 1996. Recent approaches to estimating Engel curves, Journal of Economics 63(2): 187- 212. http://dx.doi.org/10.1007/BF01258672

Fernández de Guevara, J.; Maudos, J.; Pérez, F. 2005. Market power in European banking sectors, Journal of Financial Services Research 27(2): 109-137.

http://dx.doi.org/10.1007/s10693-005-6665-z

Fernández de Guevara, J.; Maudos, J.; Pérez, F. 2007. Integration and competition in the European financial markets, Journal of International Money and Finance 26(1): 26-45.

http://dx.doi.org/10.1016/j.jimonfin.2006.10.008

Fethi, M. D.; Pasiouras, F. 2009. Assessing bank efficiency and performance with operational research and artificial intelligence techniques: a survey, European Journal of Operational Research 204(2): 189-198. http://dx.doi.org/10.1016/j.ejor.2009.08.003

Freixas, X.; Rochet, J.-C. 1997. Microeconomics of banking. Cambridge, MA: MIT Press.

Fried, H. O.; Lovell, C. A. K.; Schmidt, S. S. (Eds.). 2008. The measurement of productive efficiency and productivity change. Oxford: Oxford University Press.

http://dx.doi.org/10.1093/acprof:oso/9780195183528.001.0001 
Fu, X. M.; Heffernan, S. 2009. The effects of reform on China's bank structure and performance, Journal of Banking \& Finance 33(1): 39-52.

http://dx.doi.org/10.1016/j.jbankfin.2006.11.023

Färe, R.; Grosskopf, S. 2004. New directions: efficiency and productivity. Boston, London, Dordrecht: Kluwer Academic Publishers.

Hannan, T. H. 1991. Bank commercial loan markets and the role of market structure: evidence from surveys of commercial lending, Journal of Banking \& Finance 15: 133-149.

http://dx.doi.org/10.1016/0378-4266(91)90042-K

Hannan, T. H.; Berger, A. N. 1991. The rigidity of prices: evidence from the banking industry, American Economic Review 81: 938-945.

Hicks, J. R. 1935. Annual survey of economic theory: the theory of monopoly, Econometrica 3(1): 1-20. http://dx.doi.org/10.2307/1907343

Hintze, J. L.; Nelson, R. D. 1998. Violin plots: a box plot-density trace synergism, The American Statistician 52(2): 181-184. http://dx.doi.org/10.1017/CCOL0521382483

Härdle, W. 1990. Applied nonparametric regression. Cambridge: Cambridge University Press.

Illueca, M.; Pastor, J. M.; Tortosa-Ausina, E. 2009. The effects of geographic expansion on the productivity of Spanish savings banks, Journal of Productivity Analysis 32(2): 119-143.

http://dx.doi.org/10.1007/s11123-009-0138-6

Jennen-Steinmetz, C.; Gasser, T. 1988. A unifying approach to nonparametric regression estimation, Journal of the American Statistical Association 83(404): 1084-1089.

http://dx.doi.org/10.1080/01621459.1988.10478705

Koetter, M.; Kolari, J. W.; Spierdijk, L. 2012. Enjoying the quiet life under deregulation? Evidence from adjusted Lerner indices for U.S. banks, The Review of Economics and Statistics 94(2): 462-480. http://dx.doi.org/10.1162/REST_a_00155

Lerner, A. P. 1934. The concept of monopoly and the measurement of monopoly power, The Review of Economic Studies 1(3): 157-175. http://dx.doi.org/10.2307/2967480

Li, Q. 1996. Nonparametric testing of closeness between two unknown distribution functions, Econometric Reviews 15: 261-274. http://dx.doi.org/10.1080/07474939608800355

Li, Q.; Racine, J. S. 2007. Nonparametric econometrics: theory and practice. Princeton, Oxford: Princeton University Press,

Maudos, J.; Fernández de Guevara, J. 2004. Factors explaining the interest margin in the banking sectors of the European Union, Journal of Banking \& Finance 28(9): 2259-2281.

http://dx.doi.org/10.1016/j.jbankfin.2006.10.028

Maudos, J.; Fernández de Guevara, J. 2007. The cost of market power in banking: social welfare loss vs. cost inefficiency, Journal of Banking \& Finance 31(7): 2103-2125.

Maudos, J.; Fernández de Guevara, J. 2008. El sector bancario español en el contexto europeo: desarrollo reciente y retos futuros. Fundación BBVA, Bilbao.

Neumark, D.; Sharpe, S. A. 1992. Market structure and the nature of price rigidity: evidence from the market consumer deposits, Quarterly Journal of Economics 107: 657-680.

http://dx.doi.org/10.2307/2118485

Panzar, J. C.; Rosse, J. N. 1987. Testing for "monopoly" equilibrium, Journal of International Economics 35(4): 443-456.

Petersen, M. A.; Rajan, R. G. 1995. The effect of credit market competition on lending relationships, Quarterly Journal of Economics 110(2): 407-443. http://dx.doi.org/10.2307/2118445

Reichstein, T.; Dahl, M. S.; Ebersberger, B.; Jensen, M. B. 2010. The devil dwells in the tails, Journal of Evolutionary Economics 20(2): 219-231. http://dx.doi.org/10.1007/s00191-009-0152-x 
Rhoades, S. A. 1997. Research on IO topics in banking: an introduction and overview, Review of Industrial Organization 12: 1-8. http://dx.doi.org/10.1023/A:1007769127555

Rogers, K. E. 1998. Nontraditional activities and the efficiency of U.S. commercial banks, Journal of Banking \& Finance 22: 467-482. http://dx.doi.org/10.1016/S0378-4266(98)00020-X

Ruppert, D.; Carroll, R. J. 2000. Spatially-adaptive penalties for spline fitting, Australian and New Zealand Journal of Statistics 42: 205-224. http://dx.doi.org/10.1111/1467-842X.00119

Ruppert, D.; Wand, M. P.; Carroll, R. J. 2003. Semiparametric regression. Cambridge: Cambridge University Press. http://dx.doi.org/10.1017/CBO9780511755453

Silverman, B. W. 1984. Spline smoothing: the equivalent variable Kernel method, The Annals of Statistics 12(3): 898-916. http://dx.doi.org/10.1214/aos/1176346710

Simar, L.; Wilson, P. W. 2007. Estimation and inference in two-stage, semi-parametric models of productive processes, Journal of Econometrics 136(1): 31-64.

http://dx.doi.org/10.1016/j.jeconom.2005.07.009

Simar, L.; Wilson, P. W. 2011. Two-stage DEA: caveat emptor, Journal of Productivity Analysis 36(2): 205-218. http://dx.doi.org/10.1007/s11123-011-0230-6

Tortosa-Ausina, E.; Armero, C.; Conesa, D.; Grifell-Tatjé, E. 2012. Bootstrapping profit change: an application to Spanish banks, Computers \& Operations Research 39(8): 1857-1871.

http://dx.doi.org/10.1016/j.cor.2010.04.017

Turk Ariss, R. 2010. On the implications of market power in banking: evidence from developing countries, Journal of Banking \& Finance 34(4): 765-775.

http://dx.doi.org/10.1016/j.jbankfin.2009.09.004

Rolf FÄRE is Professor of Economics, and Agricultural and Resource Economics at Oregon State University. Prior to arriving at OSU in 1998, he was a Professor of Economics at Southern Illinois University at Carbondale. His research is rooted in the areas of production and duality theory. Using formal mathematical models, he has developed an axiomatic theory of production, which has proved useful in explaining economic phenomena including "The Law of Diminishing Returns" and "Scaling of Production," among others. His research effort is documented in 12 books, over 200 refereed journal articles, and over 50 contributions to books. The articles have appeared in leading journals including American Economic Review, Econometrica, Journal of Economic Theory and Economic Theory, among others. One indicator of the impact of this work is the fact that I am an ISI most highly cited scholar in the area of economics and finance. He also serves on the editorial board of two journals.

Shawna GROSSKOPF is Professor Emeritus at Oregon State University. Her main fields of research are Public Economics, Performance Measurement and Labor Economics. Professor Grosskopf has taught courses in public economics, microeconomics, and performance measurement. Her research includes theoretical work in performance measurement with a broad array of empirical applications including public sector performance, education, health and environmental productivity. She has published in leading journals such as American Economic Review, Journal of Econometrics, Review of Economics and Statistics, Journal of Urban Economics, Management Science, Journal of Public Economics, or the Journal of Productivity Analysis among many others. She serves as Associate Editor for Journal of Productivity Analysis and is on the Editorial Board of Health Care Management Science. She also was recipient of the Kerstin Hesselgren Chair in 1996 in honor of the first woman in the Swedish Parliament and spent 6 months at University of Gothenburg. She also has an honorary doctorate from Gothenburg.

Joaquín MAUDOS is Professor of Economic Analysis at the University of Valencia and Senior Researcher at the Ivie. His specialist fields are banking and regional economics. He has been visiting researcher at the Florida State University (USA), the College of Business at Bangor University (UK) and the University of Glasgow, He has also been consultant for the European Commission. He 
has jointly published ten books and more than seventy articles in specialized journals, both national and international (including Annals of Regional Science, Economics Letters, Entrepreneurship and Regional Development, Journal of Banking and Finance, Journal of Comparative Economics, Journal of Financial Services Research, Journal of International Money and Finance, Manchester School, Regional Studies, Review of Income and Wealth, European Journal of Finance, among others). He is member of the Editorial Board of Economics Research International and director of several competitive projects (Ministry of Science and Innovation, BBVA Foundation, etc.).

Emili TORTOSA-AUSINA is Associate Professor of Applied Economics at the University Jaume I (Spain) and Associate Researcher at the Ivie. His main fields of research are efficiency and productivity analysis, banking and finance, and regional economics. He has also made contributions in the area of international economics and economic geography, creating a database on indicators of international economic integration. He has been visiting researcher at the Universitat Autònoma de Barcelona, University of New South Wales (Sydney, Australia), Oregon State University (USA), Universidad Diego Portales (Santiago de Chile) and University of Leicester (UK). He has jointly published several books and articles in specialized journals, both national and international including European Economic Review, Economic Geography, World Development, Studies in Nonlinear Dynamics and Econometrics, Journal of Regional Science, Journal of Productivity Analysis, or European Journal of Operational Research, among others. 